\title{
Changing trends in traditional Mojari craft
}

\author{
MEENU SRIVASTAVA AND NEHA SHARMA
}

Received: 11.09.2014; Revised: 13.11.2014; Accepted: 26.11.2014

See end of the paper for authors' affiliations

\section{MEENU SRIVASTAVA}

Department of Textiles and Apparel Designing, College of Home Science, Maharana Pratap University of Agriculture and Technology, UDAIPUR (RAJASTHAN) INDIA Email: meenuclt@yahoo.com
ABSTRACT : Rajasthan has a rich and long tradition of leather crafts. Each village had its families of leather workers. The juti, mojari or pagarkhi are leather shoes and slippers worn by both men and women of all communities (http://trade.indiamart.com). Mojari is a generic name for handcrafted ethnic footwear produced in India and Pakistan. Mojari is the staple footwear of rural Rajasthan. In Rajasthan there are about a hundred thousand households engaged in the production of this traditional hand stitched shoes made out of coarse vegetable -tanned leather, which are known locally as Mojari. The best varieties are found in Jaipur, Jodhpur, Barmer, Bikaner, Jaisalmer and Dausa. In Jaipur the embroidery on the Mojari is done on velvet while in Jodhpur on leather with proficient golden ornamentation speak of gorgeousness and high skill of artisans. The present paper highlights the changing trends in Mojaris craft in Rajasthan.

KEY WORDS: Mojari, Changing, Trend, Technology, Mass media, Fashion

n HOW TO CITE THIS PAPER : Srivastava, Meenu and Sharma, Neha (2014). Changing trends in traditional Mojari craft. Asian J. Home Sci., 9 (2) : 555-560. 